\title{
The Usage of ADDIE Model in the Development of a Philosophical Inquiry Approach in Moral Education Module for Secondary School Students
}

\author{
Hafizhah Zulkifli1,2, Khadijah Abdul Razak',2, Mohd Reduan Mahmood1,2 \\ ${ }^{1}$ National University of Malaysia, Bandar Baru Bangi, Malaysia \\ ${ }^{2}$ Ministry of Education Malaysia, Putrajaya, Malaysia \\ Email: hafizhah_zulkifli@ukm.edu.my, khadijah.razak@ukm.edu.my,reduan@smkpp16.edu.my
}

How to cite this paper: Zulkifli, H., Razak, K. A., \& Mahmood, M. R. (2018). The Usage of ADDIE Model in the Development of a Philosophical Inquiry Approach in Moral Education Module for Secondary School Students. Creative Education, 9, 2111-2124. https://doi.org/10.4236/ce.2018.914153

Received: August 16, 2018

Accepted: October 23, 2018

Published: October 26, 2018

Copyright $\odot 2018$ by authors and Scientific Research Publishing Inc. This work is licensed under the Creative Commons Attribution International License (CC BY 4.0).

http://creativecommons.org/licenses/by/4.0/

(c) (i) Open Access

\begin{abstract}
Nowadays the process of teaching and learning in Malaysia (especially in terms of Moral Education) are still unable to promote moral reasoning and critical thinking. Thus, the solution to this predicament is to provide teachers with an effective module for the development of moral reasoning and critical thinking among students. The purpose of this research was 1) to describe the usage of the ADDIE model for the development of a Philosophical Inquiry approach in Moral Education (PIME) modules, and 2) to identify the content validity of the module. The ADDIE model contained five phases, namely analysis, design, development, implementation, and evaluation. Then, the researchers conducted a survey to assess the content validity of the module. The researchers also made some changes to the stimulus materials to fit the duration of the Moral Education lessons. The data were validated by six experts in the fields of Philosophical Inquiry and Moral Education. The results showed that the PIME module had a high content validity ( $>70$ percent). It meant that this module was validated and ready for use.
\end{abstract}

\section{Keywords}

Philosophical Inquiry Approach, Moral Education, Content Validity

\section{Introduction}

Moral Education is one of the core subjects in the Malaysian school system. It is compulsory for non-Muslim students to learn Moral Education in school while Muslim students learn Islamic Education. The aims of Moral Education, ac- 
cording to the Standard Curriculum for Secondary Schools, are to instill moral reasoning in decision-making and to come up with solutions for moral problems based on moral principles. In order to achieve these goals, Moral Education focuses on three domains, namely moral reasoning, moral action, and moral feeling (Kurikulum Standard Sekolah Menengah, 2015). Therefore, it is essential for a Moral Education teacher to teach and instill these three domains in the students.

Since 1960, several approaches have been used in Moral Education (Chang, 2002) to help teachers teach effectively in the classrooms. According to (Chang, 2002; Chang, 2003), some approaches that have been used in Moral Education were value inculcation, cognitive moral development, rational construction, value explanation, value analysis, social action, self-reflection, Farmington Trust project, and humanism curriculum project. In addition, new approaches that have been used in Moral Education in Malaysia include skills-based approach, domain approach, and caring approach (Chang, 2003). All these approaches are appropriate for use in the Malaysian context.

There are several issues in the teaching and learning of Moral Education. For example, the students are not interested in the subject (Barone, 2004). This is because the teachers usually emphasize on the memorization of values and jotting down of notes (Balakrishnan, 2002). According to the students, there were not many activities as teachers just went through the themes and asked the students to memorize the themes as well as their definitions. The students felt that they were not given the opportunity to voice out their opinions (Appoo, 2009).

Next, the teaching and learning of Moral Education stress on the preparation for exams (Barone, 2004) since the students need to pass the exams (Balakrishnan, 2002). Some of the students frequently score A's in the exams because they have practiced on past-year questions, not because they are moral people (Hoon, 2010; Balakrishnan \& Shoniah, 2014).

Additionally, the lecture technique is still widely used in the classroom-based Moral Education (Chia, 2007). It involves explanations and elaborations of the topic. As a result, the classroom environment becomes passive so the students do not generate ideas or think about the topic (Che Abd Rahman, 2007).

Also, the teachers ask questions that are fact-based and require only lower order thinking skills. Even worse, they ask a lot of questions in one go. For example, the teachers usually ask close-ended questions whose answers are "true" or "false", never or ever, as well as "yes" or "no" (Che Abd Rahman, 2007). As a result, the students lose focus in the classroom owing to the lack of questions that require critical thinking.

Indeed, the teachers often use the discussion technique in Moral Education, but unfortunately, the students are still passive and quiet during the discussions. The teacher might pick a name to make the student talk, but the teacher still 
dominates the discussion by giving explanations, and so on. Hence, the discussions fail to make the students think critically.

Apart from critical thinking, another important element in Moral Education is moral reasoning. In Malaysia, moral reasoning is tested in the Sijil Pelajaran Malaysia (SPM) examination to evaluate students' moral reasoning abilities (Jeevajothi, 1997). Moral reasoning is a process whereby an individual decides on what he/she ought to do during a moral dilemma (Rest, 1975). One way to enhance moral reasoning is by applying moral dilemma in the teaching of Moral Education (Gage \& Berliner, 1988). However, the teachers have revealed that they were not exposed to moral dilemmas and had no guidance on the conduction of Moral Education lessons using moral dilemmas (Appoo, 2009).

Finally, the teachers usually use textbooks and notes in Moral Education. According to the teachers, the textbooks are good, easy to use, and have plenty of information as well as activities. The teachers have complained that there were very few materials in the market, especially those that promoted moral reasoning and critical thinking (Appoo, 2009). Therefore, there is a need to provide teachers with materials or modules that contain guidelines in order to enhance the students' moral reasoning and critical thinking skills. The objective of this research is to explain the usage of an ADDIE model in the development of a Philosophical Inquiry approach in Moral Education and to assess the content validity of the module.

\section{Methodology}

\subsection{Research Design}

The goal of the instructional design was to help educators improve their teaching methods in the presence of appropriate materials and methods. It was a system of procedures for the development of education and training programs in a consistent as well as reliable manner. According to (Gustafson \& Branch, 2007), instructional design is a complex process that is creative, active, and interactive. Several systematic instructional design processes have been described by (Dick \& Carey, 1996; Gagne, Briggs, \& Wager, 1992; Kemp, Morrison, \& Ross, 1998; Smith \& Ragan, 1998) as well as the ADDIE model.

According to (Gustafson \& Branch, 2007; Molenda, 2003), the ADDIE model is an acronym of an organized process that consists of five steps, namely analysis, design, development, implementation, and evaluation as shown in Figure 1.

The researcher used the ADDIE model in the development of a philosophical inquiry approach for the Moral Education module. The reason was that, the researcher believed that this instructional model would help educators improve the accuracy of their teaching methods in an attempt to achieve the objectives of the lessons. The instructional designers have claimed that the usage of 


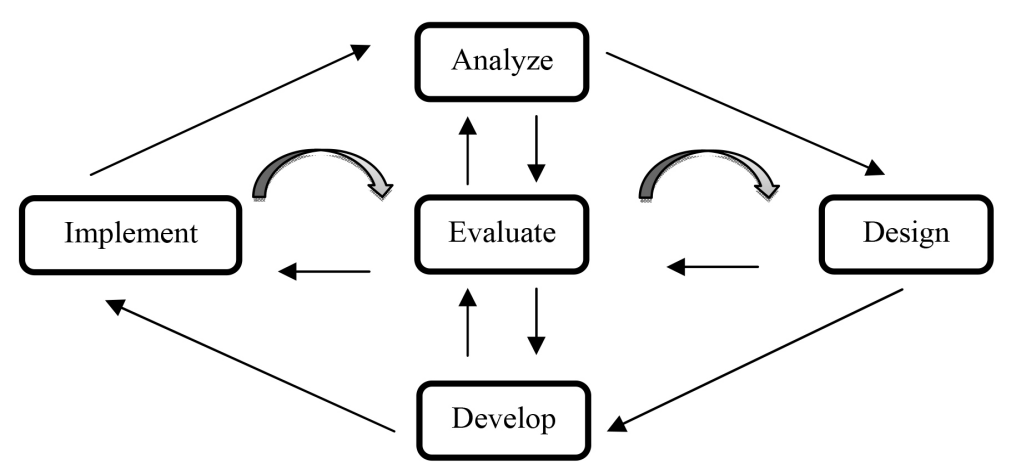

Figure 1. Core elements of ADDIE model (Seels \& Glasgow, 1990).

systematically-designed procedures could make the instructions more effective, efficient, and relevant than those created from less rigorous planning instructions (Gustafson \& Branch, 2007).

In the analysis phase, the problem had to be clarified and the objectives defined. In the designing phase, a theory that befitted the objectives had to be adopted. Then, in the development phase, the contents of the module like lesson plans and activities needed to be constructed. As for the implementation phase, the module had to be piloted. Finally, feedback collection was required during the evaluation phase.

In this research, the content validity of the module was evaluated by six experts in the fields of philosophical inquiry and Moral Education. Then, a survey was conducted to collect data. The questionnaire was constructed with reference to Russell (1974) and adapted according to the following objectives of the module: 1) this module suited the target population; 2) this module could be well-implemented; 3) this module was suitable for the allocated lesson time; 4) this module could enhance moral reasoning; as well as 5) this module could enhance critical thinking.

There were several steps in the assessment of the content validity of the PIME module. First, the researcher combined the lesson plans and exercises for all eleven sessions and named it as a teacher's manual. Then, the researcher met with the supervisor and discussed the module. The researcher also gave a soft copy of the module to the supervisor. The supervisor then gave feedback and comments to the researcher in person or by email. Next, the researcher corrected the module according to the comments. Subsequently, the researcher invited six experts to evaluate the validity of the module. The experts provided comments and criticism on the ways by which the module had to be improved. Following the evaluation, the researcher modified the module according to the comments and suggestions of the experts. Finally, the researcher analyzed the content validity of the module and reported the results.

The content validity was analyzed using the following formula:

$$
\frac{\text { Total score expert }(x)}{\text { Maximum Score }} \times 100=\text { Content validity achievement level }
$$




\subsection{Overview of Procedure of ADDIE Model}

\subsubsection{Analysis Phase}

The ADDIE Model started with the analytic phase, which often included the assessment of needs, clarification of problems and establishment of goals (Gustafson \& Branch, 2007). In this stage, the researcher performed some document analyses and gathered information by studying the current Moral Education curriculum. Then, the researcher looked into the teachers' and students' problems, goals, objectives, as well as teaching/learning environment, apart from the learners' knowledge.

The researcher conducted several interviews to clarify the problems faced by students during the teaching and learning processes. The researcher employed focused-group interviews which consisted of two groups with six students each. As per the findings, the teachers did not teach them how to think. Rather, the teachers only asked them to think independently, answer the teachers' questions, and complete exercises. Some examples of the responses are as follows;

“....think independently" (FG12DU44)

"(The) teacher asked (me) to stand up and answer it (the question)" (FG2DU48)

\section{"...the teacher only gave exercises" (FG2DU54)}

Next, the students claimed that the teachers always wrote notes on the whiteboard and asked them to copy the same into their notebooks. Also, the teachers always gave lectures on the topics.

"Copy into notebook, exercises" (FG2DU45)

"She talks to herself" (FG2DU13)

From the interviews, it could be concluded that the teachers used traditional teacher-centered methodologies, and the teaching-learning process did not emphasize on moral reasoning and critical thinking.

\subsubsection{Designing Phase}

The design phase concerned the design of objectives, specification of activities, analyses of the subject matter, and planning of lessons. It also included the determination of the methods to be used, with reference to the objectives. The objective of the PIME module was to enhance the students' critical thinking and moral reasoning. Thus, the researcher decided to include the potential methods of instruction (including pedagogy of philosophical inquiry) and Kohlberg Stages of Moral Development in the module.

$\mathrm{P} 4 \mathrm{C}$ is a comprehensive programme for the teaching of thinking. It began in the late 1960s when Lipman, a Philosophy professor at Colombia University, realized that his undergraduate students lacked reasoning and judgement skills (Naji, 2005). Then, he started to ponder over the reason for the phenomenon. He stated that while children who were four, five, and six years old were full of curiosity, creativity, and interest, and that they never stopped asking for further explanations, by the time they were eighteen, they became passive, uncritical, and bored with learning (Fisher, 2013). Therefore, he believed that it was too late 
to teach reasoning skills to college students and that the skill should be taught during childhood (Naji, 2005). He said:

"I began to think that the problem I was seeing at the university could not be solved there, that thinking was something that had to be taught much earlier before thinking habits became entrenched, so that by the time a student graduated from high school, skillful, independent thinking would have become a habit."

Lipman contended that Philosophy for Children did not just emerge out of nowhere. It is founded on the recommendations of John Dewey and the Russian educator Lev Vygotsky, who emphasized the necessity for teaching of thinking, instead of mere memorization (Lipman, 2017). He further explained that there were some philosophers and psychologists who were also influential figures in P4C. Examples included Justus Buchler, Jean Piaget, Gilbert Ryle, George Herbert Mead, and Ludwig Wittgenstein (Lipman, 2017).

It was important to note that the aim of $\mathrm{P} 4 \mathrm{C}$ was not to convert children into little philosophers, but to help them think better than they think now. The more quickly they could adapt to philosophy, the better they would develop thinking skills, reasoning, and judgment (Lipman, 2017).

Next, the researcher used the Kohlberg Stages of Moral Development in order to enhance moral reasoning among students. Lawrence Kohlberg introduced a new paradigm of moral development (which deviated from the socialization view of moral development) in the cognitive moral development approach. In the 1930s, the dominant view of moral development was the socialization view, which claimed that moral development was a matter of learning, accepting, and internalization of the norms of one's culture, as well as behaving in conformity to them. For instance, if the norms of one's culture claimed that it was alright to slurp while eating soup, then it was morally right to do so. If one's culture had norms against extramarital sex, then the same was wrong (Rest \& Narvaez, 1994).

In 1950, Kohlberg came up with a new assumption that it was the individual who determined what was morally right and wrong; not the society. The individual interpreted situations, derived psychological and moral meanings from social events, as well as made moral judgements. Kohlberg claimed that moral judgement was the most interesting process of moral development.

Kohlbergian research identifies three levels of moral development: preconventional, conventional, and postconventional (see Table 1). Each level is comprised of two stages of reasoning. At the primary level (preconventional) the individual understand the notions of "right" and "wrong" in terms of consequences of action (punishment, rewards, exchange of favors). Right action is defined in stage 2 (Instrumental Relativist Orientation) as that which satisfies one's own needs. Next at conventional level, stage 3 (Good Boy nice Girl) emphasizes behavior that will please or helps others, thus gaining approval from others for the decision maker. At stage 4 (Law and Order) the individual takes the perspective of a generalized member of the society. Finally, as the individual emphasizes 
Table 1. Kohlberg's stages of moral development.

\begin{tabular}{ccc}
\hline $\begin{array}{c}\text { Level of Moral } \\
\text { Development }\end{array}$ & Stages & Explanation \\
\hline $\begin{array}{c}\text { Level 1: } \\
\text { Pre-Conventional } \\
\text { Focus on Self }\end{array}$ & Stage 1 & Punishment and Obedience Orientation \\
Level 2: & Stage 2 & Instrumental Relativist Orientation \\
Conventional: & Stage 3 & "Good Boy-Nice Girl" Orientation \\
Focus on Others & Stage 4 & Law and Order Orientation \\
Level 3: & Stage 5 & Social-Contract Legalistic Orientation. \\
Post conventional & Stage 6 & Universal Ethical Principle Orientation \\
\hline
\end{tabular}

the possibility of changing law based open rational consideration of social unity the individual at post-conventional level specifically at stage 5 (Social-Contract Legalistic Orientation). Stage 6 (Universal Ethical Principle Orientation) is defined by the decision-maker's conscience in accord with self-chosen ethical principles appealing to logical comprehensiveness, universality and consistency (Elm \& Weber, 1994).

The researcher used the Philosophical Inquiry (PI) approach in the creation of lesson plans. The lesson plans contained the titles of the topics, stimulus materials, learning outcomes, lines of inquiry, formative evaluations, comments, and reflection. Then, the researcher created exercises that were adapted from Kohlberg's theory of Moral Development (especially moral dilemma).

\subsubsection{Development Phase}

In the designing phase, the methods of instructional delivery were chosen, the learning objectives created, and the theory to be implemented in the module selected. Subsequently, the development phase entailed the preparation of lesson plans and activities for eleven sessions. The development of the Philosophical Inquiry methods for the Moral Education module was in accordance with the Form Two syllabus. This module would guide the teachers in the enhancement of the students' levels of moral reasoning and critical thinking. The topics are as shown in Table 2.

Five aspects were considered during every teaching-learning session via the Philosophical Inquiry methods (see Table 3). First, the students were seated in a $\mathrm{U}$ shape. Then, the students took turns to read a short text. After that, the teacher asked the students to generate higher order thinking skills questions and write it on the white board. The questions were classified into themes and were discussed accordingly. Finally, the students need to answer the exercises given and make a conclusion pertaining to the objective of the lesson.

The PIME module started with the provision of the students with the stimulus materials (i.e. short texts, pictures, or videos that could make students think). In terms of the short stories, the students took turns to read one sentence each until the end of the story. After that, the students had to pose several questions which required critical thinking based on the stimulus given. In this module, the 
Table 2. Topics of PIME module.

\begin{tabular}{|c|c|c|c|}
\hline Session & Topic & Leading ideas & Materials \\
\hline 1 & Volunteers & $\begin{array}{l}\text { Importance and effects of getting } \\
\text { involved in volunteering activities }\end{array}$ & Picture of several volunteers helping the community \\
\hline 2 & $\begin{array}{l}\text { Respecting Women's } \\
\text { Rights is Everyone's } \\
\text { Responsibility }\end{array}$ & $\begin{array}{l}\text { Importance of respecting and } \\
\text { appreciating the rights of } \\
\text { female workers }\end{array}$ & $\begin{array}{l}\text { Video showing discrimination of women. } \\
\text { (https://www.youtube.com/watch?v=qY404OZOnEQ) }\end{array}$ \\
\hline 3 & Vandalism & Effects of Vandalism & $\begin{array}{l}\text { Video report by ASTRO AWANI. } \\
\text { “Third-class mentality threatens MRT’s sophistication.” } \\
\text { (https://www.youtube.com/watch?v=Wggz3dqm92A) }\end{array}$ \\
\hline 4 & The Wise Consumer & $\begin{array}{l}\text { Importance of educating consumers } \\
\text { about their rights and evaluating the } \\
\text { acts of cheating by sellers }\end{array}$ & $\begin{array}{l}\text { Video showing the methods sellers use to cheat buyers. } \\
\text { (Shopkeepers Amazing Knight Machine Tricks to cheat customers) } \\
\text { (https://www.youtube.com/watch?v=ABVGrIZ0ysM) }\end{array}$ \\
\hline 5 & $\begin{array}{l}\text { Road Safety is Our } \\
\mid \text { Responsibility }\end{array}$ & Causes and effects of road accidents & Picture of a road accident \\
\hline 6 & Protecting Coral Reefs & $\begin{array}{c}\text { Importance of protecting coral reefs } \\
\text { and the effects of coral reef } \\
\text { destruction }\end{array}$ & Story text of coral reef thefts \\
\hline 7 & Children's Rights & $\begin{array}{l}\text { Importance of protecting children's } \\
\text { rights and the effects of denying the } \\
\text { rights of children }\end{array}$ & Video of 'Our Children in Cotabato Street.' \\
\hline 8 & Respecting Parents & $\begin{array}{l}\text { The importance and impact of } \\
\text { respecting our parents. }\end{array}$ & $\begin{array}{l}\text { Video of a mother (umi) find the peaceful life at } \\
\text { (senior care house of Selangor Zakat) } \\
\text { https://www.youtube.com/watch?v=wYfBovp9eII }\end{array}$ \\
\hline 9 & Callen dilemma & Should or shouldn't steal & Adaption from Kohlberg moral dilemma \\
\hline 10 & Doctor's dilemma & $\begin{array}{l}\text { Should or shouldn't doctors give } \\
\text { more medicine }\end{array}$ & Adaption from Kohlberg moral dilemma \\
\hline
\end{tabular}

Table 3. Steps of philosophical inquiry.

\begin{tabular}{|c|c|c|}
\hline No & Steps & Details \\
\hline 1 & Seating & The students were seated in a U shape position \\
\hline 2 & Reading & $\begin{array}{l}\text { The students took turns to read the short text. This is a stimulus material and it is optional. There are also } \\
\text { stimulus materials using pictures and videos. In this case, the student does not need to read the short story } \\
\text { but observe the video or picture. }\end{array}$ \\
\hline 3 & Questioning & $\begin{array}{l}\text { After the reading session or observing the video or pictures, the teacher asked the student to generate } \\
\text { several higher order thinking questions and write it on the white board. }\end{array}$ \\
\hline 4 & Discussion & The questions were classified into themes and were discussed accordingly. \\
\hline 5 & Closure & $\begin{array}{l}\text { Then the students need to answer the exercises given and make a conclusion pertaining to the objective of } \\
\text { the lesson. }\end{array}$ \\
\hline
\end{tabular}

researcher included some examples of the questions that were in line with the topic. Accordingly, the teachers had to guide the students according to the line of inquiry provided.

During the question-posing session, the teachers were asked to guide the students in the generation of questions that required higher order thinking (HOT) skills. In the initial part of the session, the teachers were allowed to ask the students to work in groups of three or four. When the students have posed ques- 
tions as a group, the teachers could then reduce the number of groups. When the students were trained to pose questions in groups, they could indirectly create their own HOT questions.

The students were free to raise the HOT questions as long as the questions were in accordance with the line of inquiry and the topic. The questions and the corresponding students' names had to be written on the whiteboard. After that, the teachers and the students selected the questions that were to be discussed. Some examples of the HOT questions are as follows:

What do you understand from the meaning of "voluntary"?

And what is the meaning of "a volunteer"?

Why is it important to become a volunteer?

Is volunteerism a good action? Explain your reasons.

During the discussion, the teachers acted as the facilitators and guides. The students were free to voice their opinions as there was no wrong answer. However, they had to provide evidences for their opinions. The discussion included an agreement or disagreement over an idea, and the teachers were supposed to guide the students to state their ideas clearly and precisely.

After the discussion, the students were given exercises to examine their understanding of the topic. The exercises also contained dilemma which required critical thinking or moral dilemma. Again, the students needed to provide evidences for their answers. Finally, the students were asked to make a conclusion for the topic.

Apart from the development of content for moral reasoning, the researcher used three Kohlberg moral dilemmas, each of which had no single correct answer. The main objective was not to find a solution; rather, the students had to defend their answers with reasons. They also had to stress why their opinions were better than the others'. The students were free to voice out their opinions in a non-judgmental manner.

In this case, the teachers as a facilitators only guided the students by asking questions, apart from encouraging them to challenge each other's answers with their reasoning and thinking skills (Appoo, 2009). According to (Appoo, 2009), the teachers also had to be a good listener to identify the problems faced by the students during the discussion of an issue.

\subsubsection{Implementation Phase}

After thoughtful analysis, designing and development, the instructions should then be implemented. In this stage, the implementation of the module was initially implemented in the pilot of PIME module, followed by interventional PIME module (the PIME module proper).

- Pilot Philosophical Inquiry in Moral Education (PIME) module

First, the researcher met with the principals of several secondary schools to ask for permission to execute the pilot module. After obtaining permission from the principals, the researcher met with the afternoon-session senior assistants since the Form Two classes were held in the afternoon. Next, the researcher met with the Moral Education teachers. Then, the researcher obtained the schedules 
and syllabus of Moral Education.

The pilot of PIME module lasted six sessions over six weeks (i.e. one session per week). The duration of each session was one hour. During the piloting, the teacher was supervised by the experts in the Philosophical Inquiry approach. One of the comments from the experts was that the PIME module could not be completed in an hour as the teachers did not have time to finish the exercises. So, the experts recommended the conversion of the stimulus materials from short stories to pictures or videos. Furthermore, the experts recommended that the same set of induction and stimulus materials be used in the PIME module. Next, the experts advocated for specific times for generating questions, discussion, and exercises.

- Intervention of PIME Module

The interventional PIME Module was conducted for eleven weeks. The researcher chose one class to be the treatment group and one class to be the control group. The treatment group was exposed to PIME Module while the control group underwent the conventional approach. Table 4 shows the administration of the intervention on the treatment group from week one to week three. Then, the module was implemented from week four until week fourteen and finally, conducted evaluations in week fifteen.

\subsubsection{Evaluation Phase}

The evaluation process consisted of formative and summative evaluations as well as revisions. Formative evaluation involved data-collection in order to identify the revisions that were needed for the instructions. Meanwhile, summative evaluation involved data-collection in order to assess the absolute instructions. Revisions involved the making of changes with reference to the data from the formative evaluations.

During the implementation of the PIME module, formative evaluations occurred when the experts supervised the teachers and gave comments for improvement. The researcher then revised the module and made some changes according to the comments. Next, the experts demonstrated the proper execution of the pedagogy of philosophical inquiry in the lessons. Then, the teachers took over the same for the rest of the session. As for the summative evaluations, several students were interviewed to obtain their feedback pertaining to the module.

\section{Results}

Results of the content validity of the module show that, the overall score was $73.2 \%$. Since the score was $>70 \%$, the contents validity of the PIME module had good validity (see Table 5).

\section{Discussion}

The results have shown that the module was applicable, apart from being able to improve the critical thinking and moral reasoning skills of secondary school 
Table 4. Steps of implementation of PIME module.

\begin{tabular}{|c|c|}
\hline Week & Activities \\
\hline Week 1 & $\begin{array}{l}\text { The researcher discussed and met the principles, evening senior assistant and Moral } \\
\text { Education teacher }\end{array}$ \\
\hline $\begin{array}{l}\text { Week } 4 \text { to } \\
\text { Week } 14\end{array}$ & Implementation of PIME module according to the syllabus \\
\hline Week 15 & Evaluation of the PIME module \\
\hline
\end{tabular}

Table 5. Content validity of PIME module.

\begin{tabular}{cccc}
\hline No & Statement & Percent & Expert review \\
\hline 1 & This module meets the population target & $76 \%$ & Accept \\
2 & This module can be implemented perfectly & $80 \%$ & Accept \\
3 & This module is suitable according to the time allocated & $70 \%$ & Accept \\
4 & This module can enhance moral reasoning & $74 \%$ & Accept \\
5 & This module can enhance critical thinking & $66 \%$ & Accept \\
& & $73.2 \%$ & Accept \\
\hline
\end{tabular}

students. This was due to the high content validity of PIME module (73.2 percent). A content validity of $>70$ percent was considered to be high (Nordin, 1995; Talib, Mohamad, \& Wahab, 2015). This was consistent with (Appoo, 2009), who has obtained a content validity of $>70$ percent as well.

This study employed the ADDIE model for the enhancement of teaching and learning in education, especially in Moral Education. Previous researches have also used the ADDIE model for improving the teaching and learning process in education. Examples of subjects included Arabic language (Nasohah, Abd Gani, \& Md Shaid, 2015), multimedia (Arkun \& Akkoyunlu, 2008), online languages (Colpaert, 2006)), chest radiography (Cheung, 2016), as well as teaching and learning in kindergartens (Bacotang \& Mohamed Isa, 2016).

This study had a few practical and theoretical implications. From the practical aspect, the research has shown that the learning module had high validity, apart from befitting the target of enhancing critical thinking and moral reasoning skills of the students. Therefore, the teachers can use this module as a guideline to systematically plan the teaching of Moral Education. By implementing this module, the teachers can also achieve the said objectives effectively.

In addition, the module has changed the role of the teacher from a teacher-centered approach to a student-centered approach. The teachers only played a minor role (i.e. a facilitator) in the initiation of discussions among their students. Hence the students could freely voice out their opinions. As for the theoretical aspect, this module has provided the teachers with new knowledge on the improvement of thinking skills.

Based on the implementation of the module, the researcher would like to suggest that more learning modules on Philosophical Inquiry be used in Moral 
Education. Primary school students should be exposed to the module to enhance their critical thinking and moral reasoning skills at an early stage, so that the students would be able to think and make better decisions.

\section{Conclusion}

Overall, the development of PIME module was systematic and feasible since it applied the ADDIE model. The ADDIE model provided a basis for the development of education modules, was easy to use, and could be implemented in the school curricula. The module had high content validity and was applicable to use for secondary school students. It is hoped that this module will contribute to the development of a more practical approach towards the teaching Moral Education in Malaysia.

\section{Acknowledgements}

The authors express their appreciation to Ministry of Education Malaysia (MOE) state Education Department, districts Education officers, School Principle, teachers and students for their involvement in this research.

\section{Conflicts of Interest}

The authors declare no conflicts of interest regarding the publication of this paper.

\section{References}

Appoo, P. (2009). Development and Evaluation of Moral Reasoning Module for the Teaching and Learning of Moral Education. Ph.D. Thesis. Pulau Pinang: University Sains Malaysia.

Arkun, S., \& Akkoyunlu, B. (2008). A Study on the Development Process of a Multimedia Learning Environment according to the ADDIE Model and Student's Opinions of the Multimedia Learning Environment. Interactive Educational Multimedia, 17, 1-19.

Bacotang, J., \& Mohamed Isa, Z. (2016). Aplikasi Model ADDIE dalam pembangunan Modul Awal Literasi (Modul A-Lit) untuk kanak-kanak Taska.

Balakrishnan, V. (2002). Penggunaan Dilemma Real-Life Dalam Pengajaran Pendidikan Moral. Tesis Sarjana. Kuala Lumpur: Universiti Malaya.

Balakrishnan, V., \& Shoniah, S. (2014). Moral Education in Tamil Primary Schools in Malaysia: A Look into Reality. Asia Pacific Journal of Educators and Education, 29, 95-103.

Barone, T. (2004). Moral Dimension of Teacher-Student Interactions in Malaysian Secondary Schools. Journal of Moral Education, 28, 475-489.

Chang, L. H. (2002). Perkembangan Domain Moral dalam Pengajaran dan Pembelajaran Sains Sosial. Kuala Lumpur: Seminar Kebangsaan Pengajaran dan Pembelajaran Sains Sosial, Universiti Malaya.

Chang, L. H. (2003). Pendekatan Terkini dalam Pendidikan Moral. Kuala Lumpur: Kursus Orientasi Jurulatih Utama Pendidikan Moral KBSR/KBSM (semakan), Fakulti Pendidikan, Universiti Malaya.

Che Abd Rahman, A. B. (2007). Pengetahuan Kandungan dan Pedagogi Guru Pendidikan 
Moral Tingkatan Empat di Sebuah Sekolah. Tesis Doktor Falsafah. Kuala Lumpur: Universiti Malaya.

Cheung, L. (2016). Using the ADDIE Model of Instructional Design to Teach Chest Radio-Graph Interpretation. Journal of Biomedical Education, 1-6.

Chia, Y. L. (2007). Alternative Method of Teaching Moral Values: Concretization of Moral Values. Perak: Seminar Penyelidikan Pendidikan Institut Perguruan Batu Lintang.

Colpaert, J. (2006). Pedagogy-Driven for Online Language Teaching and Learning. CALICO Journal, 23, 477-497. https://doi.org/10.1558/cj.v23i3.477-497

Dick, W., \& Carey, L. (1996). The Systematic Design of Instruction (4th ed.). New York: Harper Collins.

Elm, D. R., \& Weber, J. (1994). Measuring Moral Judgment: The Moral Judgment Interview or the Defining Issues Test? Journal of Business Ethics, 13, 341-355. https://doi.org/10.1007/BF00871762

Fisher, R. (2013). Teaching Thinking: Philosophical Enquiry in the Classroom (4th ed.). Bloomsbury.

Gage, N. L., \& Berliner, D. C. (1988). Educational Psychology. Boston: Houghton Mifflin Company.

Gagne, R. M., Briggs, L. J., \& Wager, W. W. (1992). Principles of Instructional Design (4th ed.). New York, NY: Harcount Brace Janovich College Publishers.

Gustafson, K. L., \& Branch, R. M. (2007). What Is Instructional Design? In R. A. Reiser, \& J. V. Dempsey (Eds.), Trends and Issues in Instructional Design and Technology (pp. 10-16). New Jersey: Pearson Education.

Hoon, C. L. (2010). Proceedings of the 4th International Conference on Teacher Education (pp. 3-12). Indonesia, Bandung.

Jeevajothi (1997). Keberkesanan Perbincangan Dilemma Moral dalam Perkembangan Peringkat Penaakulan Moral di Kalangan Pelajar Tingkatan Empat. Kuala Lumpur: University of Malaya.

Kemp, J., Morrison, G., \& Ross, S. (1998). Designing Effective Instruction (2nd ed.). New York, NY: Merill.

Kurikulum Standard Sekolah Menengah (2015). Pendidikan Moral Tingkatan 1. Putrajaya: Kementerian Pendidikan Malaysia.

Lipman, M. (2017). The Institute for the Advancement of Philosophy for Children (IAPC) Program. In S. Naji, \& R. Hashim (Eds.), History, Theory and Practice of Philosophy for Children: International Perspectives (pp. 3-11). London: Routledge.

Ministry of Education Malaysia (2016). Standard Curriculum Secondary School. Putrajaya: Ministry of Education Malaysia.

Molenda, M. (2003). In Search of the Elusive ADDIE Model. Performance Improvement, 42, 34-36. https://doi.org/10.1002/pfi.4930420508

Naji, S. (2005). An Interview with Matthew Lipman. Thinking: The Journal of Philosophy for Children, 17, 23-29. https://doi.org/10.5840/thinking20051744

Nasohah, U. N., Abd Gani, M. I., \& Md Shaid, N. (2015). Model ADDIE dalam proses reka bentuk modul pengajaran: Bahasa Arab tujuan Khas di Universiti Sains Islam Malaysia sebagai contoh.

Nordin, A. B. (1995). Penilaian Afektif. Kajang: Masa Enterprise.

Rest, J. R. (1975). Development in Moral Judgement of Moral Issues. Minneapolis: University of Minnesota Press. 
Rest, R. J., \& Narvaez, D. (1994). Moral Development in the Professions: Psychology and Applied Ethics. Mahwah, NJ: Lawrence Erlbaum Associated.

Russell, J. D. (1974). Modular Instruction: A Guide to the Design, Selection, Utilization and Evaluation of Modular Materials. New York, NY: Publishing Company.

Seels, B., \& Glasgow, Z. (1990). Exercises in Instructional Design. Colombus, OH: Merill Publising Company.

Smith, P. L., \& Ragan, T. J. (1998). Instructional Design (2nd ed.). New York, NY: Merill.

Talib, J. A., Mohamad, Z., \& Wahab, N. A. (2015). Validity and Reliability of Careeer Exploration Module. Middle East Journal of Scientific Research, 23, 2639-2644. 